\title{
PENGARUH PENATAAN POSISI TEMPAT DUDUK TERHADAP KETAHANAN DUDUK PESERTA DIDIK DALAM PROSES PEMBELAJARAN
}

\author{
Safaruddin $^{1}$, Ainul Mardiyah ${ }^{2}$, Rahmah Sari Dewi $^{3}$, Agmi Almanawara $^{4}$ \\ ${ }^{1,2,3,4}$ Universitas Negeri Padang
}

\begin{abstract}
This article discusses how classroom management of seating arrangements could affect the behavior of students who often walk around in class. Seating arrangements were one of the most important things because of the presence of face-toface meetings between students and teachers in the classroom. This face-to-face was used so that the teacher can control and supervise every behavior of the students in the classroom so that the learning process can run well and effectively. The method used to find out students who experience problems in sitting resilience used observation and questionnaire methods. This research was qualitative in nature which aims to explain how the influence of arrangement of seat position on the resilience of students is expected to reduce the behavior of students who often take a walk in the classroom when the learning process takes place. This research was conducted in one of the Public Elementary Schools in Padang, West Sumatra. This research in its implementation was oriented to first grade students. The results of this study state that after students were given a seating position structuring program, students experience change but the changes have not been significant
\end{abstract}

Keyword: seating position, sitting resistance

\begin{abstract}
Abstrak: Artikel ini membahas bagaimana pengelolaan kelas terhadap penataan posisi tempat duduk yang dapat mempengaruhi perilaku peserta didik yang sering berjalan-jalan di kelas. Pengaturan tempat duduk merupakan salah satu hal terpenting karena adanya tatap muka antara peserta didik dan guru didalam kelas. Tatap muka ini digunakan agar guru dapat mengontrol dan mengawasi setiap perilaku siswa-siswa didalam kelas sehingga proses pembelajaran bisa berjalan dengan baik dan efektif. Metode yang digunakan untuk mengetahui peserta didik yang mengalami masalah dalam ketahanan duduknya digunakan metode observasi dan kuesioner. Penelitian ini bersifat kualitatif yang bertujuan untuk menjelaskan bagaimana pengaruh penataan posisi tempat duduk terhadap ketahanan duduk peserta didik yang diharapkan dapat mengurangi perilaku peserta didik yang sering berjalan-jalan didalam kelas saat proses pembelajaran berlangsung. Penelitian ini dilaksanakan di salah satu SD Negeri yang berada di Padang, Sumatera Barat. Penelitian ini dalam pelaksanaannya diorientasikan pada peserta didik kelas satu. Hasil penelitian ini menyatakan bahwa setelah peserta didik diberikan program penataan posisi tempat duduk, peserta didik mengalami perubahan namun dalam perubahan tersebut belum bersifat signifikan.
\end{abstract}

Kata Kunci: Posisi tempat duduk, Ketahanan duduk

\footnotetext{
'Universitas Negeri Padang, Email: safaruddin[366回fip.unp.ac.id

${ }^{2}$ Universitas Negeri Padang, Email: mardiyahainul355国gmail.com

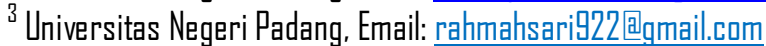

${ }^{4}$ Universitas Negeri Padang, Email: Agmialmanawara国gmail.com
} 


\section{PENDAHULUAN}

Pengelolaan kelas dalam proses pembelajaran sangat diperlukan agar proses belajar mengajar dapat berjalan dengan baik dan dapat berlangsung dengan nyaman. Bagi sebagian peserta didik penataan tempat duduk merupakan hal yang sangat berpengaruh ketika belajar, masing-masing peserta didik memiliki kenyamanan tersendiri agar peserta didik memiliki ketahanan duduk dalam menerima pelajaran yang diberikan oleh guru. Pengaturan tempat duduk didalam kelas juga dapat mempengaruhi kinerja peserta didik tersebut. Sebagian peserta didik lebih dapat dengan mudah menerima pelajaran ketika mereka duduk dibangku depan, sebagian peserta didik lainnya lebih nyaman menerima pelajaran ketika mereka duduk dibangku bagian tengah dan belakang maupun menggunakan model tempat duduk setengah lingkaran.

Guru sebagai seorang pendidik harus mampu menata lingkungan fisik kelas dengan baik. Melalui penataan kelas yang tepat maka akan tercipta suasana belajar yang kondusif, selain itu siswa juga akan mendapat dorongan dan rangsangan untuk lebih semangat dalam mengikuti proses pembelajaran. Penataan lingkungan fisik kelas dapat berupa penataan tempat duduk (Lestari, dkk, 2017).

Sejalan dengan hal itu Richards menghidupkan ruang kelas dengan antusiasme dan pembelajaran diperlukan guru yang berbakat dalam menghasilkan suasana yang dapat membuat peserta didik menjadi lebih baik dan fokus, sehingga peserta didik dapat fokus dalam mengerjakan tugasnya dan dapat tenang.

Ada beberapa peneliti yang melakukan penelitian mengenai penataan tempat duduk. Penelitian lain melaksanakan studi yang berfokus terutama pada hubungan langsung antara pengaturan dan perilaku peserta didik.
Pengaturan tempat duduk tradisional bermakna bagi pengaturan ruang kelas dan menjadi komponen kunci untuk perilaku peserta didik karena mempengaruhi kinerja kelas, tetapi ada permasalahan dimana untuk meningkatkan efektivitas desain ruang kelas tersebut khususnya yang berkaitan dengan pengaturan tempat duduk harus dilakukan studi lebih lanjut tentang pengaruh latar belakang budaya peserta didik (Haghighi \& Jusan, 2012).

Penelitian yang dilakukan Mansyur (2013) menyatakan hasil pengujian hipotesis diperoleh bukti bahwa rata-rata skor hasil belajar Statistik Pendidikan mahasiswa yang duduk diposisi depan secara signifikan lebih tinggi dari pada rata-rata skor hasil belajar Statistik Pendidikan mahasiswa yang duduk diposisi belakang.

Sedangkan dalam penelitian yang dilakukan oleh Kusumaningrum (2017) mendapatkan hasil dari SD Negeri yang berada di Kecamatan Talun, dari ke empat SD yang ada, peneliti mengambil hasil dari SD Negeri 3 Talun bahwa tingkat prestasi belajar peserta didik yang duduk diposisi depan memiliki tingkat prestasi belajar sedang, sedangkan pada peserta didik yang duduk di posisi tengah mendapatkan tingkat prestasi belajar sedang dan rendah, dan untuk peserta didik di posisi duduk dibelakang mendapatkan tingkat prestasi belajar yang sedang.

Oleh karena itu dalam penelitian ini dilakukan pengelolaan kelas berupa pengaturan posisi tempat duduk terhadap peserta didik yang mengalami Attention problems/ Inatensivitas yang menyebabkan ia memiliki perilaku sering berjalan-jalan saat pembelajaran di kelas. Peneliti mengamati bahwa salah satu penyebab peserta didik memiliki perilaku sering berjalan-jalan di kelas tersebut dikarenakan peserta didik ditempatkan diposisi duduk paling belakang sehingga peserta didik tidak fokus dalam belajar. 
Oleh sebab itu, peneliti melakukan penelitian berupa pemindahan posisi tempat duduk peserta didik ke depan, yang bertujuan agar peserta didik lebih fokus dalam pembelajaran dan dapat mengurangi perilaku berjalan-jalannya didalam kelas tersebut.

\section{TINJUAN PUSTAKA}

Belajar merupakan salah satu aktivitas yang memerlukan konsentrasi ataupun pemusatan perhatian yang baik sehingga peserta didik mampu menerima pembelajaran, namun dalam hal ini terdapat peserta didik yang tidak memiliki konsentrasi yang baik atau mengalami gangguan pemusatan perhatian yang sering disebut attention problems atau inatensivitas.

$\begin{array}{llr}\quad \text { Pada } & \text { peserta didik yang } \\ \text { mengalami } & \text { gangguan } & \text { pemusatan } \\ \text { perhatian } & \text { (attention } & \text { problems }\end{array}$
/immaturity) memiliki perilaku seperti konsentrasi yang jelek, sering bingung dan implusif (Sumekar, 2009). Sedangkan pada peserta didik inatensivitas menunjukkan tidak adanya perhatian atau tidak menyimak dalam pembelajaran. Penderita mengalami kesulitan dalam memusatkan perhatian terhadap sesuatu yang sedang dihadapinya. Berikut ciri-ciri peserta didik yang mengalami inatensivitas : a) gagal menyimak hal yang rinci, b) kesulitan bertahan pada satu aktivitas, c) tidak mendengarkan sewaktu diajak berbicara, d) sering tidak mengikuti instruksi, e) kesulitan mengatur jadwal tugas dan kegiatan, f) sering menghindar dari tugas, $\quad$ g) sering kehilangan barang yang dibutuhkan untuk tugas, h) sering beralih perhatian oleh stimulus dari luar, dan i) sering lupa dalam kegiatan sehari-hari (Marlina, 2011).

Pemusatan perhatian merupakan hal yang tidak bisa diabaikan didalam kegiatan pembelajaran, karena tanpa adanya pemusatan perhatian di dalam kegiatan pembelajaran maka kegiatan pembelajaran yang dilakukan tidak dapat berjalan secara optimal (Sukmawati, 2012).

Salah satu akibat dari attention problems/inatensivitas ialah peserta didik sering menunjukkan perilaku seperti tidak mendengarkan guru saat pembelajaran dan sering berjalan-jalan di kelas.

Supaya pembelajaran dapat berjalan lebih baik dan efektif, maka perlu dilakukannya penataan kelas. Penataan kelas merupakan cara-cara yang ditempuh guru dalam menciptakan lingkungan kelas agar tidak terjadi kekacauan dan memberikan kesempatan kepada peserta didik untuk mencapai tujuan akademis dan sosial (Luwesty, Syaiful, \& Ekwandari, 2017).

Penataan tempat duduk menjadi salah satu pengelolaan kelas yang mudah dilakukan karena tidak memakan waktu yang lama. Penataan tempat duduk memberikan efek yang cukup besar dibandingkan penataan fisik kelas lainnya. Penataan tempat duduk berpengaruh terhadap jumlah waktu yang digunakan peserta didik untuk menyelesaikan tugas yang diberikan (Luwesty et al., 2017).

Pengaturan tempat duduk merupakan salah satu hal yang terpenting karena adanya tatap muka antara peserta didik dan guru didalam kelas. Melalui tatap muka tersebut maka guru mampu mengontrol dan mengawasi setiap perilaku siswa-siswa didalam kelas (Pangastuti et al., 2017). Hal ini juga dapat diketahui pengaturan tempat duduk yang buruk dapat memengaruhi belajar peserta didik, jadi dengan memodifikasi pengaturan tempat duduk yang sesuai dan tepat dapat menjadi metode yang sangat bagus untuk mengurangi perilaku gangguan yang memengaruhi lingkungan kelas (Haghighi \& Jusan, 2012). 


\section{METODOLOGI PENELITIAN}

Pelaksanaan penelitian ini dilakukan di salah satu SDN yang berada di kota Padang, Sumatera Barat. Waktu penelitian dimulai dari bulan Februari hingga April 2019, adapun pelaksanaan program dilakukan selama kurang lebih satu minggu.

Penelitian ini menggunakan metode kualitatif yang bertujuan untuk menyelidiki pengaruh penataan posisi tempat duduk terhadap ketahanan duduk peserta didik. Pelaksanaan program dilakukan sebanyak satu kali, dimana peneliti dibantu oleh wali kelas untuk mendapatkan informasi mengenai hasil pelaksanaan program yang telah dilaksanakan. Oleh karena itu dilakukan wawancara terhadap guru wali kelas sesudah pemberian program pada peserta didik. Subyek dalam penelitian ini adalah peserta didik yang diidentifikasi mengalami gangguan perilaku berupa sering berjalan-jalan di kelas.

\section{HASIL PENELITIAN DAN PEMBAHASAN \\ Identifikasi Masalah}

Pada tahap ini dilakukan pengumpulan berbagai informasi tentang peserta didik yang memiliki hambatan perilaku berupa sering berjalan-jalan di dalam kelas. Proses pengumpulan informasi didapat dari wawancara yang dilakukan terhadap guru dan kuesioner yang dilakukan kepada siswa-siswi yang berada di kelas satu. Dari hasil observasi yang dilakukan ditemukan bahwa: (1) sistem penataan tempat duduk yang terdapat di dalam kelas ialah formasi tradisional (baris dan kolom); (2) peserta didik yang mengalami hambatan perilaku memiliki posisi duduk di barisan belakang. Permasalahan yang ada: (1) peserta didik kurang fokus dalam memperhatikan pembelajaran; (2) pola penataan tempat duduk yang tidak dapat di ubah karena sarana yang tidak mendukung.
Adapun hasil dari wawancara yang dilakukan terhadap Kepala Sekolah dan Guru kelas didapati bahwa peserta didik yang sering berjalan-jalan dikelas adalah W. Kemudian hasil dari kuesioner yang dilakukan dikelas didapati bahwa rata-rata peserta didik memilih $\mathrm{W}$ sebagai peserta didik yang sering berjalan-jalan didalam kelas saat proses pembelajaran.

Setelah didapatkan analisis permasalahan di lapangan, tahap selanjutnya adalah melakukan rancangan program yang akan diberikan kepada peserta didik untuk mengatasi hambatan perilaku yang terjadi.

\section{Rancangan Program}

Merencanakan

suatu pembelajaran agar berjalan dengan lancar dan efektif, maka guru perlu memiliki strategi dan metode dalam proses pembelajarannya. Proses pembelajaran yang dilakukan guru menggunakan strategi ekspositori dan metode ceramah plus, yaitu metode ceramah yang digabungkan dengan tanya jawab dan pemberian tugas. Sebelumnya, dalam melaksanakan pembelajaran guru sudah menerapkan strategi dan metode tersebut, namun hal ini masih kurang efektif dalam mengatasi masalah tingkah laku peserta didik yaitu sering berjalan-jalan di kelas saat pembelajaran berlangsung.

Sebelum dilaksanakannya program penataan kelas, posisi duduk peserta didik berada di no. 13 pada gambar contoh penataan tempat duduk berikut: 


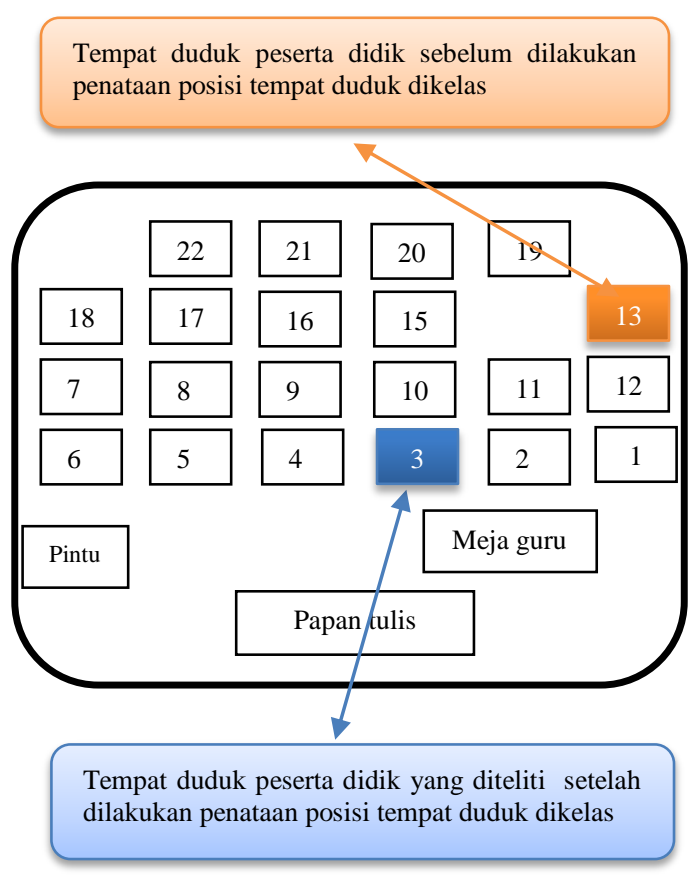

Gambar 1. Contoh penataan posisi tempat duduk

Oleh karena itu, peneliti mencoba melakukan pengelolaan kelas berupa penataan tempat duduk dimana peserta didik ditempatkan di depan nomor 3 dengan tujuan peserta didik dapat fokus dalam pembelajarannya sehingga diharapkan dapat mengurangi perilaku peserta didik berjalan-jalan saat pembelajaran berlangsung.

Peneliti bekerjasama dengan guru wali kelas dalam pelaksanaan pengelolaan tempat duduk untuk menentukan posisi tempat duduk peserta didik, selain itu peneliti melakukan pendekatan dengan peserta didik sehingga peserta didik merasa nyaman. Dari pengamatan peneliti, posisi tempat duduk yang tepat bagi peserta didik yang mengalami gangguan perilaku ini yaitu dengan menempatkan peserta didik di barisan bangku paling depan dan posisi meja peserta didik ditempatkan di dekat meja guru serta berhadapan dengan papan tulis.

Cara pertama yang dilakukan peneliti dalam melaksanaan penataan posisi tempat duduk ini, yaitu menggunakan pencabutan lot berdasarkan urutan absen kelas. Akan tetapi, dalam pelaksanaannya cara ini kurang efektif dikarenakan tempat duduk yang didapat peserta didik lain dari hasil pencabutan lot tidak sesuai dengan keinginan peserta didik dikelas. Oleh sebab itu, peneliti menggunakan cara penunjukkan secara langsung untuk memindahkan posisi tempat duduk peserta didik dibarisan depan nomor 3 atas persetujuan dan keinginan peserta didik sendiri.

Berdasarkan pelaksanaan program penataan posisi tempat duduk yang dilakukan terhadap perilaku peserta didik yang sering berjalan-jalan di dalam kelas karena kurangnya konsentrasi saat proses pembelajaran berlangsung, yang dalam pelaksanaannya dibantu oleh guru wali kelas, maka hasil yang didapat dari informasi guru wali kelas tersebut, yaitu perilaku berjalan-jalan peserta didik dikelas karena kurangnya konsentrasi dalam belajar tersebut mengalami perubahan terhadap penataan posisi tempat duduk yang dilakukan, namun perubahan tersebut belum bersifat signifikan, seperti yang pada awalnya saat peserta didik duduk dibelakang, peserta didik sering berjalan-jalan karena kurangnya konsentrasi tetapi setelah diberi program peserta didik ada mengalami perubahan pada tingkat konsentrasinya yang mengurangi sedikit perilaku berjalan-jalan peserta didik di dalam kelas.

Sebelumnya dalam segi akademikpun peserta didik tidak bermasalah, seperti peserta didik sudah mengerti dengan huruf-huruf dan penggunaannya dalam pembuatan kata ataupun kalimat, namun dalam pembelajaran peserta didik masih menunjukkan ketidakmautahuan. Peserta didik malas untuk mengerjakan tugas yang diberikan oleh guru, tetapi bila diberikan perhatian khusus dari guru yang tertuju kepada peserta didik, maka peserta didik mau untuk mengerjakan 
tugas maupun apa yang disuruh oleh guru yang mengajarnya.

\section{KESIMPULAN}

Dari hasil yang di dapat, maka dapat disimpulkan bahwa program penataan posisi tempat duduk yang dilakukan dengan cara penunjukkan secara langsung dapat digunakan dalam penelitian ini. Hasil pelaksanaan program penataan posisi tempat duduk yang ditunjuk secara langsung ini dapat mempengaruhi tingkah laku peserta didik yang diteliti, namun perubahan tersebut belum bersifat signifikan terhadap perubahan tingkah laku peserta didik yang sering berjalan-jalan dikelas saat proses pembelajaran berlangsung.

\section{DAFTAR PUSTAKA}

Haghighi, M. M., \& Jusan, M. M. (2012). Exploring Students Behavior on Seating Arrangements in Learning Environment: A Review. Procedia - Social and Behavioral Sciences, 36 (June 2011), 287294.

https://doi.org/10.1016/j.sbspro.2 $\underline{012.03 .032}$

Kusumaningrum, N. A. M. D. D. N. B. D. E. (2017). Efek posisi tempat duduk peserta didik terhadap prestasi belajar peserta didik sekolah dasar negeri di kecamatan Talun Blitar, (1), 119.

Lestari, Y. (2017). Pengaruh Penataan Tempat Duduk terhadap Hasil Belajar Siswa Pada Pembelajaran IPA Kelas V SD N 20 Kota Bengkulu, 10(1), 61-65.

Luwesty, A., Syaiful, M., \& Ekwandari, Y. S. (2017). Exploring Students Behavior on Seating Arrangements in Learning Environment: A Review, (01).

Mansyur, T. M. (2013). Pengaruh Pemberian Tugas dan Posisi Tempat Duduk Terhadap Hasil
Belajar Statisti Pendidikan, 2634.

Marlina. (2011). Aplikabilitas Metode Applied Behavior Analysis Untuk Mengurangi Perilaku Anak ADHD (Attention Deficit Hyperactivity Disorders), 16(1), $39-52$.

Pangastuti, R., Solichah, I., Islam, U., Sunan, N., Surabaya, A., \& Anak, T. P. (2017). Studi Analisis Manajemen Pengelolaan Kelas di Tempat Penitipan Anak (TPA) Khadijah Pandegiling Surabaya Ratna Pangastuti, Isnaini Solichah. 35, (2), 35-50.

Richards, J. (2012). Setting the Stage for Student Engagement, (December 2014).

https://doi.org/10.1080/00228958. 2006.10516441

Sukmawati. (2012). Potret Pemusatan Perhatian Anak Di Dalam Kegiatan Pembelajaran Di Taman Kanak-Kanak Budi Mulia Padang, 1(1), 1-13.

Sumekar, G. (2009). Anak Berkebutuhan Khusus. Padang: UNP Press. 